\title{
HOMOGENEOUS SUBSTITUTE MATERIAL MODEL FOR REINFORCED CONCRETE MODELING
}

\author{
J. SIWIŃSKI ${ }^{1}$, A. STOLARSKI ${ }^{2}$
}

\begin{abstract}
This paper outlines a method of determining the deformation and strength parameters for a hypothetical, homogeneous, substitute material which approximates the properties of heterogeneous materials in reinforced concrete elements. The model of the substitute material creates a concrete reference model, in which the static strength - deformation parameters were modified on the basis of the homogenizing function with the homogenization coefficient assumed as the effective reinforcement ratio of the reinforced concrete structural elements. The results of the comparative analysis of the numerical models using the hypothetical substitute material with experimental results for statically loaded beams and deep beams taken from the literature are presented.
\end{abstract}

Keywords: Homogeneous substitute material, Numerical analysis, Reinforced concrete modelling

\section{INTRODUCTION}

The use of a hypothetical model of a substitute material to simulate the behavior of large-size building objects of a reinforced concrete structure has a significant influence on the efficiency of the calculation procedure. The manner of behavior of the numerical model of such a structural system depends heavily on the used material model, which constitutes an integral part of the modeling procedure of the mechanism of behavior and destruction of building objects. This problem becomes particularly important in the case of analyzing the problems of dynamic response of buildings under accidental loads (explosive, impact, shock). The full procedure for constructing a computational

\footnotetext{
1 PhD., Eng., Military University of Technology, Faculty of Civil Engineering and Geodesy, 2 Gen. W. Urbanowicza Str., 00-908 Warsaw, Poland, e-mail: jaroslaw.siwinski@wat.edu.pl

${ }^{2}$ Prof., Eng., Military University of Technology, Faculty of Civil Engineering and Geodesy, 2 Gen. W. Urbanowicza Str., 00-908 Warsaw, Poland, e-mail: adam.stolarski@wat.edu.pl
} 
model requires taking into account the appropriate accidental loads, determination the characteristics of its changes in time and space, development of a solution method while taking into account the physically and geometrically non-linear dynamic analysis, selection of the appropriate structural material models, development of a numerical model of the building, and carrying out the analyze of building model behavior. Due to the level of difficulty of modeling of complex structural systems of buildings of reinforced concrete as a heterogeneous material composition of concrete and reinforcing steel, the approach based on homogenization of reinforced concrete is used.

The approach based on the homogenization of the heterogeneous reinforced concrete via the example of the structural plate is presented in [1]. Authors of the study used a division of a reinforced concrete plate over the height of the cross-section into zones of different strength parameters. A hypothetical model material for the analysis of cyclic loading was proposed. It should be noted that in the zones where reinforcement occurs increased strength parameters were used to form the layered material and then to establish the interaction between the layers. Determination of different parameters for the individual layers makes it so the material can still be treated as heterogeneous. The method of homogenization was not presented and the behavior of the material on the base of comparative analysis along with the experimental results using the proposed material model as a single layer was not tested.

Another homogenization approach was used in paper [2], in which the authors, in turn, refer to work [3]. In these works, the substitute homogeneous material was used with increased tensile strength and with increased deformation modulus in comparison with the reference material (i.e. reinforced concrete). The procedure for determining the parameters of a substitute material for the tested object relied on determining the strength characteristics of the material on the basis of only one element considered as the most critical element in the whole structure. Then, the parameters of the substitute material were determined in such a way so as to achieve the similar stresses and strain distributions as would occur in a critical reinforced concrete element.

In relation to the reinforced concrete elements and elements of the periodic microstructure, the uniform formulation of variational homogenization problems using the finite element method was used in works $[4,5]$.

The methodology of modeling reinforced concrete members based on the combination of the mechanical theory of mixtures and the framework of the Continuum Strong Discontinuity Approach using embedded crack finite elements, has been proposed for two- and three-dimensional modeling in papers $[6,7]$. 
Based on the review of existing literature, we can formulate the following conclusions: a great majority of studies concerning the modeling of the behavior of reinforced concrete buildings includes numerical analysis based on the heterogeneous material model, which is a composition of concrete and reinforcing steel together with the definition of cooperation between these materials $[1,2,8]$. No work on numerical analysis using the homogeneous model of substitute material presents a universal procedure for determining the static - strength - deformation parameters for such materials.

The purpose of this work is to develop a substitute material model for analysis of reinforced concrete structures. Achieving this goal is conditioned by the determination of the material model parameters, taking into account the type of structure, system of reinforcement, and static - strength - deformation parameters of the component materials. A universal procedure was proposed for determining the parameters of a substitute material model on the basis of the homogenization function, in which the homogenization coefficient is assumed as equal to the effective reinforcement ratio of reinforced concrete structural elements.

The confirmation of advantages in using the homogenization approach in modeling of reinforced concrete is the work of the authors of [9], in which it has been proven that the moment-curvature relationship of the cross-section with the homogeneous substitute material approximates the momentcurvature relationship of the reinforced concrete cross-section with acceptable accuracy.

\section{HOMOGENIZING APPROACH FOR DETERMINING THE PARAMETERS OF THE SUBSTITUTE MATERIAL}

According to homogenization theory, reinforced concrete as the heterogeneous composition of concrete and reinforcing steel has been replaced with a homogeneous substitute material in which all strength and deformation parameters were determined to be a purposeful modification of the appropriate parameters of the concrete reference model. A schematic diagram of reinforced concrete homogenization is presented in Fig. 1. 


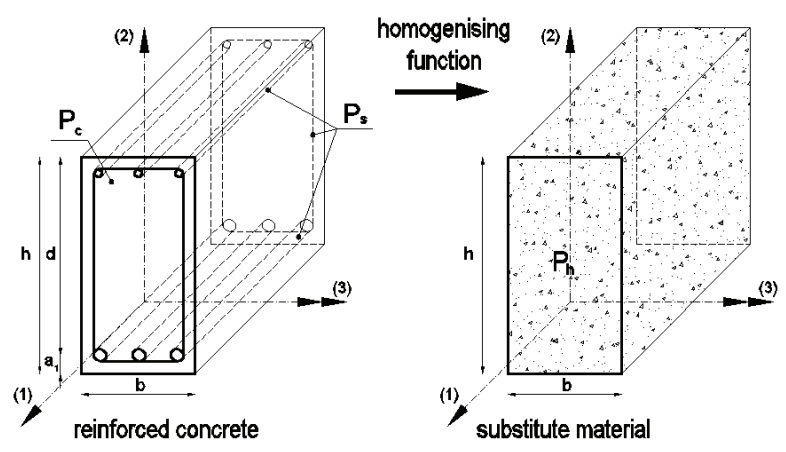

Fig. 1. Schematic diagram of reinforced concrete homogenization

The basis of the homogenization methodology of reinforced concrete elements is a method of determining the deformation - strength properties of the substitute material. The method relies on the modification of the parameters of any model concrete (i.e. the so-called reference model), as the commonly used model material with progressive damage, developed by Lubliner et al. [3], modified by Lee and Fenves [10], and incorporated into the software of the Abaqus system using the homogenizing function:

$$
P_{h}=P_{c}+F_{h} \cdot P_{S}
$$

The homogenizing function (2.1) transforms the parameters of the constituent materials of reinforced concrete; concrete $P_{c}=\left\{f_{c}\right.$ - compressive strength, $f_{c t}$ - tensile strength, $E_{c}$ - deformation modulus, $v_{c}$ - coefficient of transversal deformability, $\gamma_{c}$ - specific mass $\}$ and reinforcing steel $P_{s}=\left\{f_{y}-\right.$ plasticity limit, and $E_{s}, v_{s}, \gamma_{s}$, respectively\}, into the corresponding parameters of a homogeneous substitute material $P_{h}$ by means of the homogenization coefficient $F_{h}$, which was adopted as the effective reinforcement ratio of the reinforced concrete element:

$$
F_{h}=\rho_{\text {eff }} .
$$

The effective reinforcement ratio of the reinforced concrete element is assumed as the function:

$$
\rho_{\text {eff }}=\sqrt{\left(\rho_{1} \cdot \varphi_{y 1}\right)^{2}+\left(\rho_{2} \cdot \varphi_{y 2}\right)^{2}+\left(\rho_{3} \cdot \varphi_{y 3}\right)^{2}},
$$


where: $\rho_{i}=\left\{\rho_{1}, \rho_{2}, \rho_{3}\right\}$ - varied reinforcement ratios in the directions of $i=1,2,3, \varphi_{y i}=$ $f_{y i} / f_{y, \max }-$ normalized coefficients taking into account the varied yield limits of reinforcing steel $f_{y, i}=\left\{f_{y 1}, f_{y 2}, f_{y 3}\right\}$ in relation to the maximum yield limit $f_{y, \max }=\max \left\{f_{y i}\right\}$.

\section{CONCRETE REFERENCE MODEL}

The plastic-damage model for concrete described in detail in the papers of Lubliner et al. [3] and Lee $\&$ Fenves [10] is adopted as the reference material model. Figs. 2 (a) and (b) show the curves for uniaxial compression $\boldsymbol{\sigma}_{c}\left(\boldsymbol{\varepsilon}^{p}\right)$ and uniaxial tension $\boldsymbol{\sigma}_{c t}\left(\boldsymbol{\varepsilon}^{p}\right)$ as the basic functions determining the evolution law for stresses in relation to plastic strains. Equations of stress evolution determine the initial strengths of concrete for uniaxial compression $f_{c 0}$ and tension $f_{c t 0}$ as well as the degradation parameters $\kappa_{c}$ and $\kappa_{c t}$ determined in dependence on the specific energy of compressive deformation $g_{c}$ and tensile deformation $g_{c t}$.
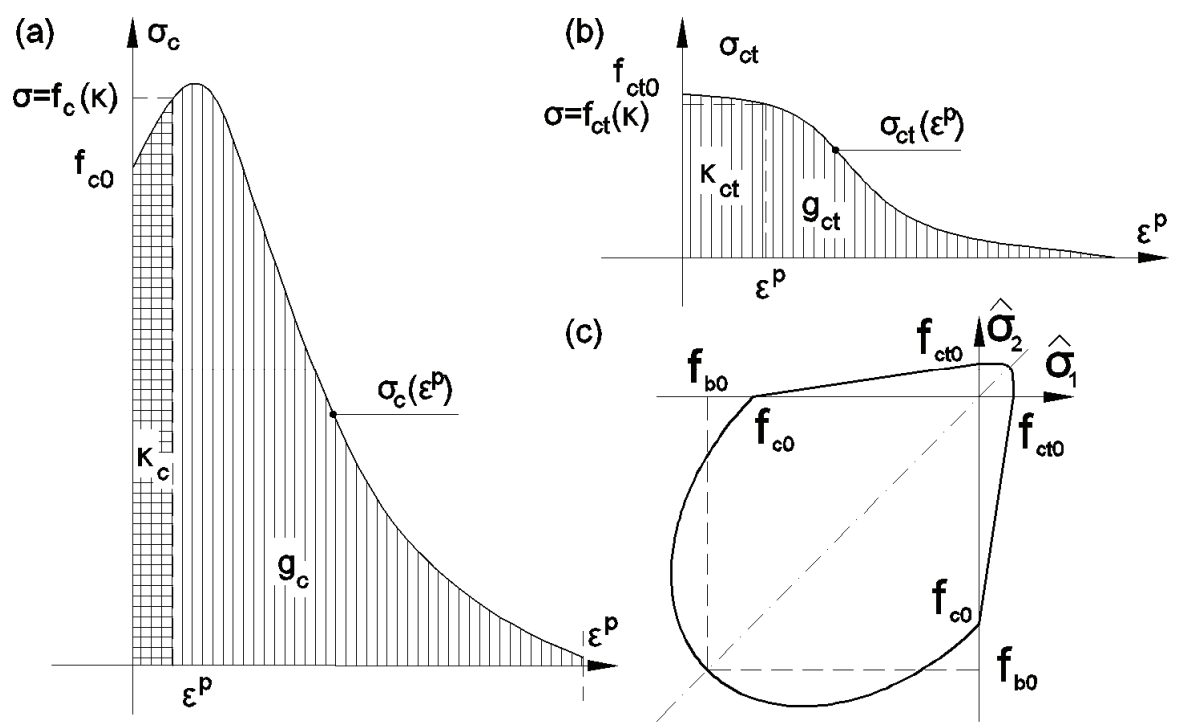

(c)

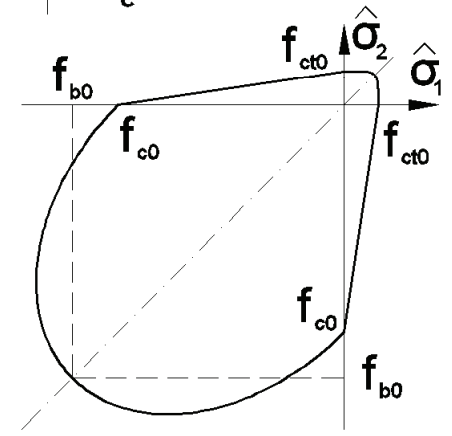

Fig. 2. The plastic-damage model for concrete: (a) evolution of uniaxial compression, (b) evolution of uniaxial tension, (c) plasticity limit function in the principal stress plane 
In turn, in Fig. 2 (c), the plasticity limit function in the principal stress plane ( $\left.\widehat{\boldsymbol{\sigma}}_{1}, \widehat{\boldsymbol{\sigma}}_{2}\right)$, is presented. This function describes the strength for symmetrical biaxial compression $f_{b 0}$ associated with the strength for uniaxial compression $f_{c 0}$ according to the relationship: $f_{b 0}=(1.16 \div 1.20) f_{c 0}$.

\section{SUBSTITUTE MATERIAL MODEL}

The reference plastic-damage model for concrete in which all strength - deformation parameters have been replaced by model parameters determined in accordance with the assumptions of the homogenization method was adopted as the substitute material model.

Taking into account the stress - strain idealizations for concrete for uniaxial compression and uniaxial tension proposed in $[3,10,11]$ as well as the elastic - perfectly plastic model for reinforcing steel, the schematic diagram of a substitute model is presented in Fig. 3.

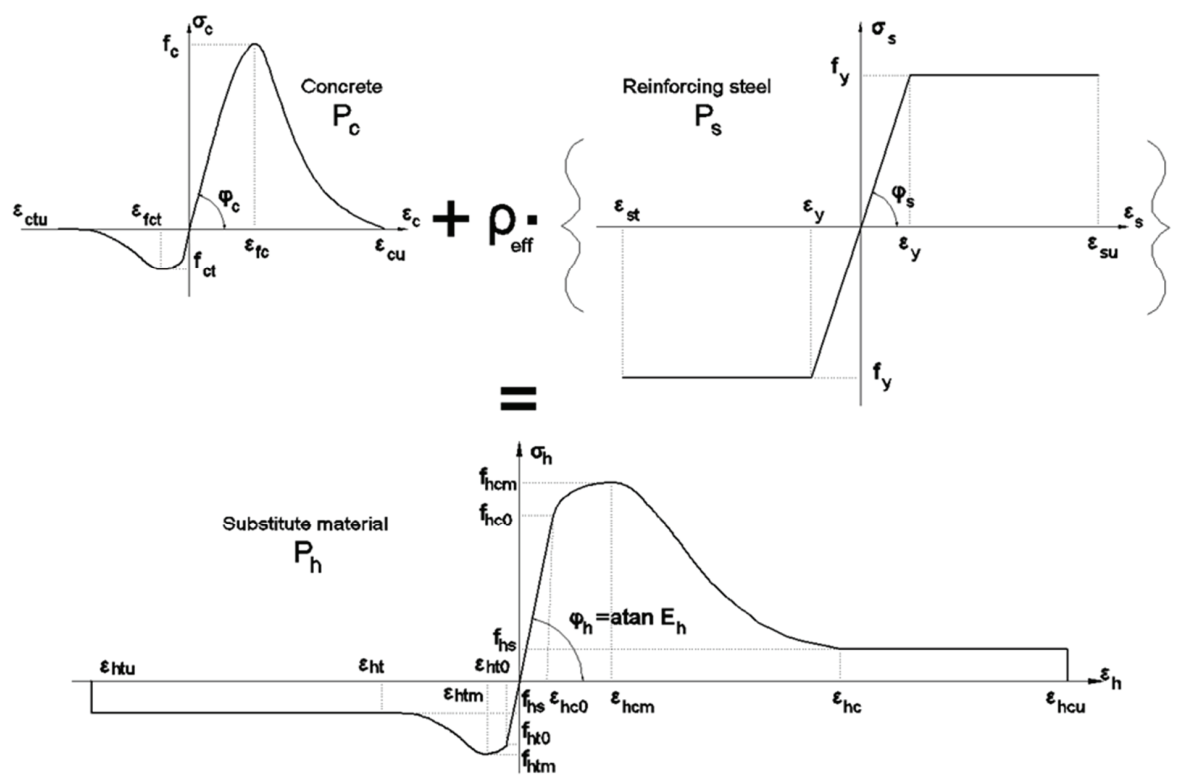

Fig. 3. Schematic diagram of a substitute material model

In the substitute material model, all the static - deformation - strength parameters have been designated in accordance with the assumptions of the homogenization method according to equations (2.1) and (2.2). 
The following model parameters are specified:

$P_{h}=\left\{f_{h c 0}-\right.$ the initial compressive strength, $f_{h t 0}-$ the initial tensile strength, $f_{h c m}-$ the maximum compressive strength, $f_{h t m}$ - maximum tensile strength, $f_{h s}$ - the minimum compressive / tensile strength, $E_{h}$ - deformation modulus, and $v_{h}$ - coefficient of transversal deformability, $\gamma_{h}-$ specific mass\}.

Moreover, the following strain limits describe the model.

$\varepsilon_{h}=\left\{\varepsilon_{h c 0}=\frac{f_{h c 0}}{E_{h}}-\right.$ the initial elastic strain in compression, $\varepsilon_{h t 0}=\frac{f_{h t 0}}{E_{h}}-$ the initial elastic strain in tension, $\varepsilon_{h c m}$ - strain corresponding to the maximum compressive strength, $\varepsilon_{h t m}-$ strain corresponding to the maximum tensile strength, $\varepsilon_{h c}$ - the initial strain corresponding to minimum compressive strength, $\varepsilon_{h t}$ - the initial strain corresponding to minimum tensile strength, $\varepsilon_{h c u}$-limit strain corresponding to minimum compressive strength (at buckling of rebar in a reinforced concrete structure), $\varepsilon_{h t u}$ - strain limit corresponding to minimum tensile strength (at rupture)\}.

\section{VERIFICATION OF THE SUBSTITUTE MATERIAL MODEL}

Verification of the substitute material model was carried out on the basis of numerical analysis for selected examples of beam and deep beam. The basis of verification was to compare the obtained results for the models of structural elements developed using the substitute material model with the experimental results for the reinforced concrete elements.

The first numerical experiment taken into consideration was the Backhouse experimental beam $C 1$ [12], for which the static scheme, the cross and the longitudinal sections, and the material data are shown in Fig. 4. 


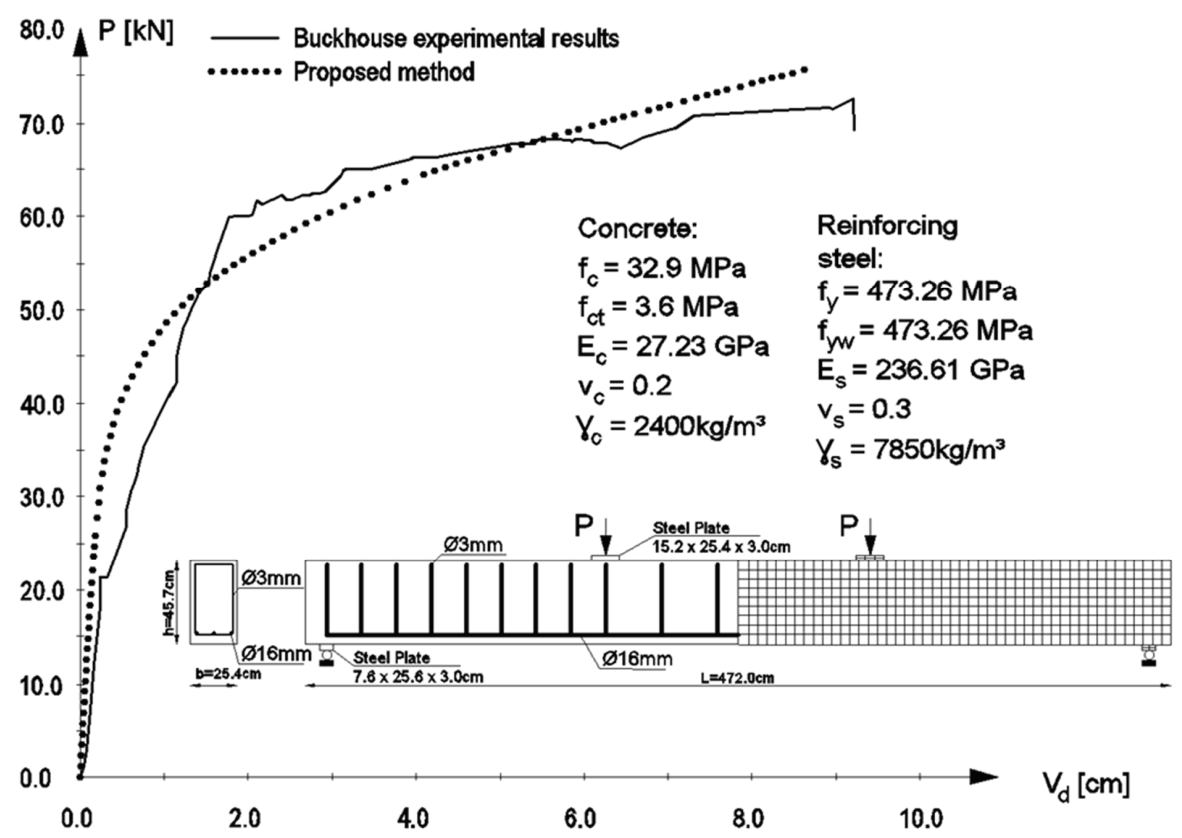

Fig. 4. Graph of the load-displacement in the midpoint of the beam

The reinforcement ratios for directions: longitudinal $\rho_{1}=0.0057$, transverse vertical $\rho_{2}=0.00025$, and transverse horizontal $\rho_{3}=0.00016$, designate, according to (2.3), the effective reinforcement ratio $\rho_{\text {eff }}=0.00571$, which was the basis for determining the substitute material parameters (2.1). The computational FE beam model was developed using the spatial division in the C3D8R type finite cubic elements (i.e. 8 nodal elements). In this model, the division of the finite element mesh in HEX solid elements measuring $\sim 50 \times 50 \mathrm{~mm}$ was introduced. Used in the beam model were 4298 finite elements connected (interacting) in 5912 nodes. The Newton-Raphson method was used to solve the problem.

Based on the numerical computations, the graph of the displacement at the midpoint of the beam in the function of load is presented in Fig. 4. It is stated that the results for the model of the homogeneous beam from the substitute material show very good agreement of the maximum force in the state of the limit load and the corresponding displacement with the experimental results for the reinforced concrete beam.

Another numerical study was carried out on the basis of Leonhardt and Walther's [10] experimental deep beam WT3, for which the static scheme, reinforcement system, and the material data are shown 
in Fig. 5. The experimental results of Leonhardt and Walther [13] are commonly used as the pattern results for comparison by other authors, e.g. Lewiński and Wojewódzki [14]. The analysis of the deep beam was performed for the so-called first level of static load carrying capacity of the deep beam, which - according to the authors of the experiment - corresponds to the attainment of the compressive strength within the normal vertical stresses in concrete in the vicinities over the supports.

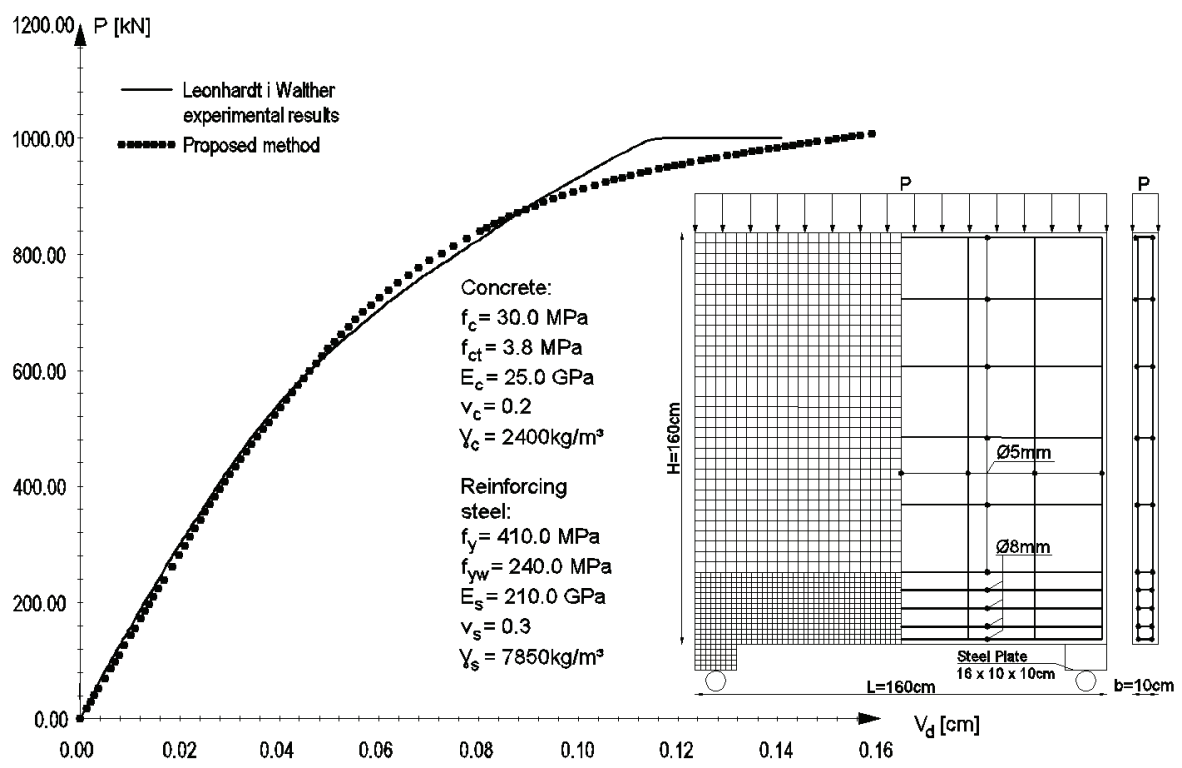

Fig. 5. Graph of the load-displacement at the midpoint of the bottom edge of deep beam

The reinforcement ratios for directions: longitudinal $\rho_{1}=0.0002$, transverse vertical $\rho_{2}=0.001$, and transverse horizontal $\rho_{3}=0.0015$, taking into account the correction coefficient for yield limits of the reinforcing steel $\varphi_{y}=0.585$, designate the effective reinforcement ratio (2.3) $\rho_{\text {eff }}=0.0018$, which is the basis for determining the substitute material parameters (2.1).

The computational FE model of the deep beam was developed using the spatial division in C3D8R type finite cubic elements ( 8 nodal elements). In the model, the division of the finite element mesh in HEX type solid elements measuring $20 \times 20 \mathrm{~mm}$, was introduced in the bottom zone corresponding to the zone of the concentrated main reinforcement where $\varnothing=8 \mathrm{~mm}$ diameter with dimensions of $40 \times 40 \mathrm{~mm}$ in the remaining upper part of the reinforced concrete deep beam WT3, Fig. 5. In the spatial division of the deep beam were used of 10360 finite elements, interacting in 13892 nodes. 
Modeling of steel supports was applied using the elongation of the geometrical profile of the deep beam (at the locations of the steel supports and of the size of these supports), and it was then assigned to the steel strength parameters. In order to use the same finite element mesh for supporting steel plates which corresponds to the division of the bottom zone of the deep beam, finite elements with dimensions of $20 \times 20 \mathrm{~mm}$ were applied.

Per the results of the numerical analysis of the homogeneous deep beam with a substitute material, the graph of the total load in the function of the displacement at the midpoint of the bottom edge was obtained, Fig. 5. The results of the numerical experiments for the homogeneous deep beam with substitute material indicate a slight $(\sim 2 \%)$ difference in the load carrying capacity and a slightly greater $(\sim 10 \%)$ difference in the maximum displacement in comparison with the experimental results for the reinforced concrete deep beam.

\section{Conclusions}

A hypothetical substitute material model for analysis of reinforced concrete structures was presented in this paper. This model was developed using the method of homogenization of reinforced concrete elements. The basis of this method is the way for determining the strength - deformation properties of the substitute material. A universal procedure was proposed for determining the parameters of a substitute material model (including compressive strength, tensile strength, deformation modulus, Poisson's ratio, and specific mass) on the basis of the homogenization function. In this function, the homogenization coefficient was assumed as equal to the effective reinforcement ratio of reinforced concrete structural elements.

This procedure enables modification of the parameters of any so-called reference concrete model. In this paper, the plastic - damage model of concrete by Lubliner et al. [3], commonly used in the Abaqus software, was adapted as the reference model. This solution allows the utilization of resources of the Abaqus software system, with the modified reference model as the substitute material model, for modeling and analysis of the structural elements.

The presented comparative analysis for beams and deep beams justifies the application of the homogeneous substitute material model for the approximate modeling of the behavior of reinforced concrete elements. The effectiveness of the methodology of modeling the structure using a homogeneous substitute material indicates the possibility of its effective use also to the numerical analysis of complex structural members and large-size buildings of reinforced concrete structures. Confirmation of the effectiveness of the proposed model can be achieved by using it to analyze the 
behavior of reinforced concrete beams and deep beams under static and dynamic loads in the works of J. Siwiński, A. Stolarski [15] and [16], as well as buildings of reinforced concrete under explosive load by J. Siwiński. A. Stolarski [17].

Depending on the degree of complexity of the computational analysis necessary, the proposed model of the substitute material can be applied to a single element (the highest degree of approximation of the homogenization coefficient), to specific areas of the structure, e.g. one storey (the intermediate level), or even to the entire structure (the lowest degree of approximation as the first approximation of solution).

\section{REFERENCES}

1. Combescure Ch., Dumontet H., Voldoire F., Homogenised constitutive model coupling damage and debonding for reinforced concreto structures under cyclic solicitations, International Journal of Solids and Structures, Vol. 50, 3861-3874, 2013.

2. Kelliher D., Sutton-Swaby K., Stochastic representation of blast load damage in a reinforced concreto building, Structural Safety, Vol. 34, 407-417, 2011.

3. Lubliner J., Oliver J., Oller S., Onate E., A plastic-damage model for concrete, International Journal Solids and Structures, Vol. 25(3), 299-326, 1989.

4. Urbański A. FE analysis of a reinforced concrete beam cross-section under shear, torsion, bending and axial force. AMCM 7TH International Conference "Analytical Models and New Concepts in Concrete and Masonry Structures",349-350, June 13-15, Krakow, Poland, 2011.

5. Urbański A. The unified finite element formulation of homogenization of structural members with periodic microstructure. Monograph 320. Krakow University of Technology Publisher, Krakow, Poland, 2005.

6. Oliver J., Linero D. L., Huespe A. E., Manzoli O. L. Two - dimensional modeling of material failure in reinforced concrete by means of a continuum strong discontinuity approach. Computer Methods in Applied Mechanics and Engineering, 197, 332-348, 2008.

7. O.L. Manzoli, J. Oliver, A. E. Huespe, G. Diaz. A mixture theory based method for three-dimensional modeling of reinforced concrete members with embedded crack finite elements. Computers and Concrete, Vol. 5, 4, 401416, 2008.

8. Luccioni B.M., Ambrosini R.D., Danesi R.F., Analysis of building collapse under blast loads, Engineering Structures, Vol. 26, 63-71, 2004.

9. Siwiński J., Stolarski A., Model of substitute material in the analysis of the bent reinforced concrete crosssection, Biuletyn WAT, vol. LXIV, nr 4, 145-163, 2015, (in Polish).

10. Lee J., Fenves G., Plastic-damage model for cyclic loading of concrete structures, Journal of Engineering Mechanics, 892-900, 1998.

11. Desayi P., Krishnan S., Equation for the stress-strain curve of concrete, Journal of the American Concrete Institute, Vol. 61, 345-350, 1964.

12. Buckohouse E.R., External flexural reinforcement of existing reinforced concrete beams using bolted steel channels, Marquette University, Milwaukee, Wisconsin, 1997.

13. Leonhardt F., Walther R., (1966). Wandartige trager, Deutscher Ausschuss fur Stahlbeton, 229, Berlin, Germany.

14. P.M. Lewiński, W. Wojewódzki. Integrated finite element model for reinforced concrete slabs. Journal of Structural Engineering ASCE, 117, 4, 1991, 1017-1038.

15. J. Siwiński, A. Stolarski. Comparative analysis of reinforced concrete beam using hypothetical model of substitute material. Bulletin of Military University of Technology, Volume LXV, Number 2, 37-48, Warsaw, 2016, (in Polish).

16. J. Siwiński, A. Stolarski. Comparative analysis of reinforced concrete deep beam using hypothetical model of substitute material, Bulletin of Military University of Technology, Volume LXV, Number 2, 49-61, Warsaw, 2016, (in Polish).

17. J. Siwiński, A. Stolarski. Modeling of buildings behavior under blast load. In: Dynamical Systems: Modelling, Springer Proceedings in Mathematics \& Statistics, DOI 10.1007/978-3-319-42402-6_27, J. Awrejcewicz (ed.), vol. 181, , 341-352, Springer International Publishing Switzerland 2016. 


\section{LIST OF FIGURES:}

Fig. 1. Schematic diagram of reinforced concrete homogenization

Rys. 1. Ideowy schemat homogenizacji żelbetu

Fig. 2. The plastic-damage model for concrete: (a) evolution of uniaxial compression, (b) evolution of uniaxial tension, (c) limit plasticity function in the principal stress plane

Rys. 2. Model plastycznego zniszczenia betonu: (a) ewolucja jednoosiowego ściskania, (b) ) ewolucja jednoosiowego rozciągania, (c) funkcja plastyczności w płaszczyźnie naprężeń głównych

Fig. 3. Schematic diagram of a substitute material model

Rys.3. Ideowy schemat modelu materiału zastępczego

Fig. 4. Graph of the load-displacement in the midpoint of the beam

Rys. 4. Wykres obciążenia w funkcji przemieszczenia punktu środkowego belki

Fig. 5. Graph of the load-displacement at the midpoint of the bottom edge of deep beam

Rys. 5. Wykres obciążenia w funkcji przemieszczenia punktu środkowego dolnej krawędzi tarczy

Received 08.09.2016

Revised 28.02.2018 


\section{MOdEl JedNORODNEgo MATERIALU ZaSTĘPCZEgo do MODELOWANIA ŻELBETU}

Slowa kluczowe: Jednorodny materiał zastępczy, Analiza numeryczna, Modelowanie żelbetu

\section{PODSUMOWANIE:}

W pracy przedstawiono model hipotetycznego materiału zastępczego do analizy konstrukcji żelbetowych. Model ten opracowano z wykorzystaniem metodyki homogenizacji elementów żelbetowych.

Podstawą metodyki homogenizacji elementów żelbetowych jest sposób określenia właściwości odkształceniowo wytrzymałościowych materiału zastępczego. Sposób ten polega na modyfikacji parametrów dowolnego modelu betonu (tj. tak zwanego modelu referencyjnego), np. powszechnie stosowanego modelu materiału plastycznego zniszczenia opracowanego przez Lublinera i.in., zmodyfikowanego przez Lee and Fenvesa i włączonego do systemu oprogramowania Abaqus, z wykorzystaniem funkcji homogenizacyjnej $P_{h}=P_{c}+F_{h} \cdot P_{s}$.

Funkcja homogenizacyjna przekształca parametry materiałów składowych żelbetu, czyli betonu $P_{c}$ i stali zbrojeniowej $P_{S}$ w odpowiednie parametry jednorodnego materiału zastępczego $P_{h}$ za pomocą współczynnika homogenizacji $F_{h}$, który przyjęto jako efektywny stopień zbrojenia elementu żelbetowego $F_{h}=\rho_{\text {eff }}$.

Efektywny stopień zbrojenia elementu żelbetowego przyjęto jako funkcję $\rho_{\text {eff }}=$ $\sqrt{\left(\rho_{1} \cdot \varphi_{y 1}\right)^{2}+\left(\rho_{2} \cdot \varphi_{y 2}\right)^{2}+\left(\rho_{3} \cdot \varphi_{y 3}\right)^{2}}$, gdzie: $\rho_{i}=\left\{\rho_{1}, \rho_{2}, \rho_{3}\right\}$-zróżnicowane stopnie zbrojenia w kierunkach $i=$ $1,2,3, \varphi_{y i}=f_{y i} / f_{y, \max }-$ znormalizowany współczynnik uwzględniający zróżnicowane granice plastyczności stali zbrojeniowej $f_{y, i}=\left\{f_{y 1}, f_{y 2}, f_{y 3}\right\}$ względem maksymalnej granicy plastyczności $f_{y, \max }=\max \left\{f_{y i}\right\}$.

Weryfikację modelu materiału zastępczego przeprowadzono na podstawie analizy numerycznej dla wybranych przykładów belki i tarczy. Podstawą weryfikacji było porównanie uzyskanych wyników dla modeli elementów konstrukcyjnych opracowanych przy użyciu modelu materiału zastępczego z wynikami eksperymentalnymi dla elementów żelbetowych.

Pierwszym rozważanym doświadczeniem numerycznym była belka doświadczalna Buckhouse'a C1. Stwierdzono, że wyniki uzyskane dla modelu jednorodnej belki z materiału zastępczego wykazują bardzo dobrą zgodność nośności granicznej i odpowiadającego przemieszczenia z wynikami doświadczenia dla belki żelbetowej.

Kolejne badania numeryczne przeprowadzono na podstawie tarczy doświadczalnej Leonhardta i Walthera WT3. Wyniki doświadczeń numerycznych dla jednorodnej tarczy z materiału zastępczego wskazują na nieznaczną ( 2\%) różnicę nośności oraz nieco większą ( 10\%) różnicę maksymalnych przemieszczeń w porównaniu z wynikami doświadczenia dla tarczy żelbetowej.

Efektywność metodyki modelowania konstrukcji przy zastosowaniu jednorodnego materiału zastępczego wskazuje na możliwość jej skutecznego zastosowania także do analizy numerycznej złożonych, wielkowymiarowych obiektów budowlanych o konstrukcji żelbetowej.

W zależności od stopnia złożoności analizy obliczeniowej proponowany model materiału zastępczego można stosować w odniesieniu do pojedynczych elementów konstrukcyjnych (najwyższy stopień aproksymacji współczynnika homogenizacyjnego), do poszczególnych obszarów konstrukcji, np. kondygnacji (pośredni stopień) lub nawet do całej konstrukcji (najniższy stopień aproksymacji jako pierwsze przybliżenie rozwiązania). 